\title{
Limits and conditions for the exploitation of alluvial aquifers in the Brazilian semi-arid region
}

\section{Limites e condições para o aproveitamento de aquíferos aluviais no semiárido brasileiro}

Everton John Camelo Alves ${ }^{1}$, Janiro Costa Rêgo ${ }^{1}$, Carlos de Oliveira Galvão ${ }^{1}$ and José Benito de Andrade Vieira ${ }^{1}$

${ }^{1}$ Universidade Federal de Campina Grande, Campina Grande, PB, Brasil

E-mails: everton.ufcg@hotmail.com (EJCA),janiro_rego@yahoo.com.br (JCR), carlos.o.galvao@gmail.com (COG),josebenitoeng@gmail.com (JBAV)

Received: November 21, 2016 - Revised: January 22, 2018 - Accepted: January 22, 2018

\begin{abstract}
Easily exploitable aquifers are formed along river beds in the Brazilian semi-arid region and present characteristics that enable the construction of underground dams. The estimate of the potential effective exploitation of these aquifers must take into account the pumping limits of the wells, the upstream groundwater inflows and the flows to downstream reaches and through the underground dam, whose reduction influences the downstream supply. The current research presents a real case study about an aquifer reach, with underground dam and wells, which was analyzed through computational model. We simulated the groundwater flow patterns according to different exploitation scenarios and found that there should be water extraction limitations to assure the required downstream flows. The limitations can be minimized through appropriate well locations and exploitation regimes, as well as through the implementation of underground dams. The definition of these measures becomes possible through the sound use of computational simulation, but their effective implementation will depend on negotiations among users at the basin scale, so that appropriate water permits can be issued.
\end{abstract}

Keywords: Hydrological and environmental modelling; Hydrogeology and groundwater; Irrigation and drainage.

\section{RESUMO}

No semiárido do Brasil, os aquíferos aluviais são de fácil aproveitamento e com características favoráveis à construção de barragens subterrâneas. A determinação do potencial efetivo de explotação desses aquíferos deve levar em consideração, além dos limites de funcionamento dos poços, a afluência subterrânea a montante da área explotada, assim como a efluência para jusante, de forma a assegurar demais usos e demandas. Neste artigo é tratado o caso de trecho de aquífero aluvial dotado de barragem subterrânea e poços, analisado por meio de modelo computacional. Simulamos os padrões de escoamento subterrâneo para diferentes cenários de explotação de água, considerando as implicações de disponibilidade hídrica para trechos a jusante. Identificamos limitações ao atendimento das demandas, causadas pela necessidade de garantir o escoamento da água subterrânea para jusante. Tais limitações, contudo, puderam ser minimizadas por meio de adequações na locação dos poços, de modificações no regime de explotação e da inserção de barragens subterrâneas. A definição destas medidas é possibilitada pela simulação computacional, mas sua implantação dependerá de negociação entre os usuários na escala de bacia, para concessão adequada das outorgas de extração da água subterrânea.

Palavras-chave: Modelagem hidrológica e ambiental; Hidrogeologia e águas subterrâneas; Irrigação e drenagem. 


\section{INTRODUCTION}

The Brazilian semi-arid region is mostly located in the country's Northeastern region, where shallow soils formed on crystalline basements prevail and present very low water accumulation and circulation capacities. However, thicker sedimentary layers also result from erosion and alluvial transport processes. Such phenomena, although locally restricted to the beds and banks of some rivers and streams, form aquifers of easy and favorable use (ALBUQUERQUE; RÊGO, 2011).

Water catchment in these aquifers, either for human supply, animal watering or irrigation purposes, is carried out through manually excavated large-diameter wells (from 1.5 to 3 meters). These wells are known in the region as "amazonas" or "cacimbão" wells, which are often lined in brick masonry. They are, as a rule, fully penetrating wells, since they cross several lithographic, sandy and boulder layers, which are interspersed by less thick, clayey or sandy-clayey layers.

Because of the geological formation process itself, the alluvial aquifers in the Brazilian semi-arid region are shallow, narrow and elongated, besides working as groundwater conduits whose predominant flow direction is axial to the watercourse. This feature favors the use of underground dams built transversely to the aforementioned main flow direction. The implementation of these dams requires digging trenches, which are subsequently filled with less permeable material (clay) or have one of their slopes covered with waterproof synthetic fabric curtain.

A dam may fully cover the cross section of the aquifer or only part of it, thus enabling the downstream, lateral or overflow. The flow containment or retardation, and the consequent water table elevation, generate conducive conditions for the location of wells in the upstream section of the dam, where groundwater exploitation tends to be concentrated in.

The water volumes to be pumped out are naturally limited by the depletion of reserves in the section, which happens when the drawdowns in the wells (dynamic levels) reach the base of the alluvial sediment package. However, in order to estimate the effective potential of the aquifer section in use (the dam and its wells), it is necessary taking into consideration additional factors other than the operating limits of the wells, namely: (a) the groundwater flow coming from the most upstream alluvial sections; and (b) the downstream flow through the dam and/or through the natural border of the aquifer. The full annulment or considerable decrease in this effluent flow will negatively affect the supply for users' demands in alluvial sections located further downstream, outside the limits of the studied site (BURTE et al., 2005).

Therefore, the interdependence between the alluvial aquifer section and the other upstream and downstream sections requires analyzing the considerable extent of the aquifer in order to allow it to be rationally used. The boundaries of the river basin where the aforementioned aquifer is located are the most appropriate ones. The need of performing the integrated management of surface and groundwater resources in the river basin becomes more evident in this case. There is close relation between the alluvial aquifer and the overlapping watercourse, which is the most important border for the aquifer recharge and discharge processes (SHANAFIELD; COOK, 2014; MONTEIRO; MONTENEGRO; MONTENEGRO, 2014; JACOBSON; JACOBSON, 2013).
It is worth analyzing the integrated management of the alluvial aquifer in the river basin area to assure proper water permits from the management agency. As the magnitude of extraction flows in these aquifers is low, users are not often required to obtain individualized permits; they are only required to be registered. The excessive drilling of wells along the alluvium can lead to its depletion and bring harm to all users. In addition, they can generate conflicts and inequalities in the access to water. Given the social and community function of these water sources, it is necessary taking into consideration the integrated management of the whole aquifer in order to enable all potential users to have access to water.

The current article investigates the limits in the exploitation of alluvial aquifer sections, under the integrated river basin management perspective, as subsidy to the concession of groundwater extraction permits. We herein treat the actual case of an alluvial aquifer, along with its underground dam and wells, as proof of concept. The local water demands for irrigation and animal watering purposes were evaluated, in a distributed way, according to each well. The behavior of the aquifer was analyzed according to the supply of these demands, under the condition of not stopping the natural downstream flow. The analysis allowed quantifying the use limitations resulting from the aforementioned condition, as well as minimizing them by changing water catchment infrastructures and by negotiating management rules.

\section{MATERIALS AND METHODS}

\section{Case study}

The irrigated perimeter of Sumé is located close to Sumé County (Paraíba State), in the Cariri semi-arid micro region, along the Sucuru River. The irrigators use groundwater from the alluvial sediment package forming the river bed and most of its banks. The current study selected the 720-m-long, varying-width aquifer whose surface comprised approximately $345,600 \mathrm{~m}^{2}$. The aquifer has six active-exploitation wells and one $33 \mathrm{~m}$-long underground dam built on canvas, which is fully penetrating down to the crystalline basement, although it partially dams the flow in the cross section of the aquifer (Figure 1).

\section{Calculating the water demands}

Field surveys were carried out in the selected area and in the irrigated perimeter, in 2015, in order to gather data concerning (1) rainfall in the river basin; (2) the time evolution of groundwater levels measured in the wells, at approximately biweekly intervals; (3) the features of the operating pumps, and their respective daily pumping periods; (4) agricultural crops and animal breeding practices, along with their consumptive water uses.

During that low-rainfall year, the aquifer received little natural recharge, which was restricted to the first months of the year. It led to the option for adopting the three-month period (approximate duration of one agricultural cycle), which started in May, to conduct the intended research. The Thornthwaite-Mather Equation (THORNTHWAITE; MATHER, 1955) was used to calculate crop evapotranspiration. The demands supplied at each well were herein estimated (Table 1). 


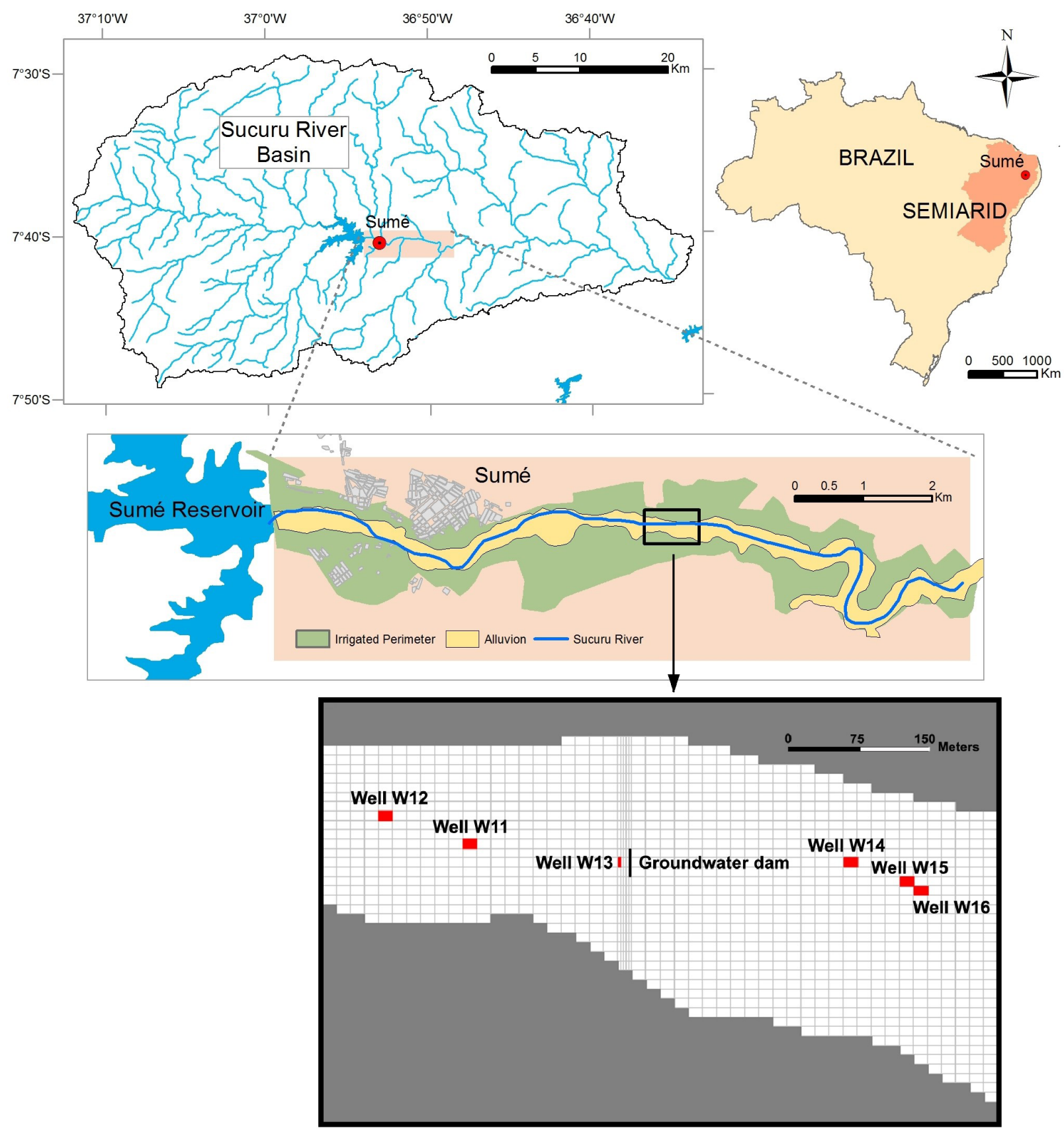

Figure 1. Study site and the constructed model.

Table 1. Irrigated area, livestock units supplied by the respective water volumes exploited, on a daily basis, in each well during the quarterly cycle in 2015.

\begin{tabular}{|c|c|c|c|c|c|}
\hline \multirow[t]{2}{*}{ Well } & \multirow{2}{*}{$\begin{array}{l}\text { Irrigated } \\
\text { area } \\
\text { (hectares) }\end{array}$} & \multirow{2}{*}{$\begin{array}{c}\text { Supplied } \\
\text { livestock } \\
\text { units }\end{array}$} & \multicolumn{3}{|c|}{$\begin{array}{c}\text { Flows exploited in each } \\
\text { well }\left(\mathrm{m}^{3} / \text { day }\right)\end{array}$} \\
\hline & & & May & June & July \\
\hline P11 & 5.00 & 0 & 99.89 & 82.78 & 78.50 \\
\hline P12 & 0.00 & 50 & 4.62 & 4.62 & 4.62 \\
\hline P13 & 1.73 & 0 & 35.31 & 29.26 & 27.75 \\
\hline P14 & 0.87 & 0 & 17.65 & 14.63 & 13.87 \\
\hline P15 & 0.87 & 0 & 17.65 & 14.63 & 13.87 \\
\hline P16 & 0.87 & 0 & 17.65 & 14.63 & 13.87 \\
\hline Total & 9.34 & 50 & 192.77 & 160.55 & 152.48 \\
\hline
\end{tabular}

\section{Modeling the aquifer}

The model of the selected area was prepared to allow analyzing the behavior of the aquifer. Groundwater flow patterns were simulated according to different well-based water exploitation scenarios. According to the herein adopted design, the relations between the remainder of the aquifer and the modeled area were assessed by taking as criterion the uninterrupted flow through its permeable boundaries.

The digital model was built in the PMWIN 7.0.31 software (CHIANG, 2005), based on the MODFLOW numerical code (MCDONALD; HARBAUGH, 1984), whose use in groundwater 
flow modeling is strongly acknowledged. This model was taken as basis for the development of several other models (BRAGA; RÊGO; GALVÃO, 2015; MONTEIRO; MONTENEGRO; MONTENEGRO, 2014; CAROL et al., 2012; YANG, 2012; BURTE; COUDRAIN; MARLET, 2011; ZUME; TARHULE, 2011).

The two-dimensional mesh comprised $15 \mathrm{~m} \times 10 \mathrm{~m}$ cells, and it was adopted in the discretization of the studied area, using the location of the dam and wells, besides the aquifer contours (Figure 1). In the case of the phreatic aquifer, its upper border was the surface of the terrain itself, whereas the bottom was the impermeable crystalline rock basement. The depths, which did not exceed $10 \mathrm{~m}$, were measured through the interpolation of data deriving from previously performed mechanical drillings (ATECEL, 1999). These drillings (40, in total) were distributed in six cross sections to the alluvium and longitudinally spaced approximately $100 \mathrm{~m}$ from one another. The number and distance between the holes in each section changed according to the width of the alluvium and to the recorded depths.

The Northern and Southern boundaries of the model, which were defined through the contact between the alluvium and the shallow soil or emerging impermeable crystalline rock, did not allow the flow to go in or out. The Eastern and Western contours, which were defined through the alluvium-alluvium contact, were permeable and presented flow depending on the hydraulic loading conditions in these borders and within the exploitation area. The groundwater flow in the modeled section would predominantly happen from the West (upstream supply) to the East (downstream discharge) under natural conditions (no pumping).

The hydraulic parameters of the aquifer used in the model were the same as those found by Vieira, Rêgo and Srinivasan (2002). These authors performed pumping tests in the P11 well and calibrated the aquifer section that included the currently modeled one. Then, values were set for hydraulic conductivity ( $\mathrm{K}=7.87 \times 10^{-4} \mathrm{~m} / \mathrm{s}$ ) and for storage coefficient (or effective porosity, in free aquifers), $\eta_{\mathrm{e}}=10 \%$.

\section{Scenario simulations}

The herein built model performed all the water flow, load and balance calculations, besides enabling the visualization of trajectories through the outlining of flow lines. It also allowed analyzing the behavior of the system and the sustainability of the exploitation in practice.

The criterion adopted in the sustainability analysis was based on the need of not having the natural groundwater flow leaving the downstream area completely interrupted at some point during the pumping period. It would gradually cause flow inversion, or part of it, at the exit border, at least until the end of the three irrigation months. Then, the demand would be supplied by volumes taken from parts of the aquifer located downstream to the activated section; however, these parts certainly also have their own demands to be met.

The first simulated scenario reproduced what actually happened in May, June and July 2015, which was herein referred to as "prevalence of the current situation". Thus, the goal was to check, through the analysis applied to the flow pattern resulting from the simulation, whether the exploitation in practice was compatible with sustainable aquifer-use conditions. The other scenarios deriving from the result of the present one aimed at finding solutions to enable the sustainable exploitation of the aquifer or to help improving its efficiency.

\section{RESULTS AND DISCUSSION}

\section{Scenario 1: prevalence of the current situation}

This scenario simulated the exploitation carried out in May, June and July 2015, i.e., all six wells in the studied area were activated at the pumping rates shown in Table 1 . The water balance in the modeled area was applied to the last 15 days of the quarterly exploitation period and presented the following values:

- Affluent volume across the borders (upstream or downstream): $1750.23 \mathrm{~m}^{3}$;

- Effluent volume across the downstream border: $8.29 \mathrm{~m}^{3}$;

- Volume pumped out of the wells: $2287.20 \mathrm{~m}^{3}$;

- Variation in the stored or withdrawn volume: $545.26 \mathrm{~m}^{3}$.

These results show that the wells consumed practically all the affluent volume coming through the borders and another part of it coming from the storage, since the effluent volume was less than $0.5 \%$ of the affluent one. The flow lines in the two-dimensional modeled area (Figure 2A) presenting the most critical situation allow the distribution of the groundwater flow between the wells distributed in the area to be clearly distinguished.

The analysis conducted according to the herein adopted criterion showed unwanted flow inversion at the Easterner border, where some flow should flow to meet the demands of the downstream perimeter. It is possible noticing that the P16 well is almost exclusively fed by this external flow. The other wells, besides being supplied by the upstream border, also consume part of the reserve in the section. It leads to the partial and localized emptying of it, fact that is distinguished in the model by the deactivation or disappearance of cells that have dried out, as it can be seen, for example, around the P11 and P13 wells. In addition, it is possible seeing decreased hydraulic loads in each well, in time, at the end of each month (Figure 2B).

\section{Scenario 2: reducing the met demand in order to allow downstream discharge}

The main way to assure the necessary groundwater flow through the Eastern border to downstream of the exploited section is to reduce pumping in the wells; it means failing to meet the calculated demands. The implementation of rates or limits, both for pumping reduction and downstream discharge, is an essentially socioeconomic and negotiation matter. In order to do so, it is essential using proper criteria based on information about water demands of other parts of the aquifer and on alternative supply possibilities such as reuse, increased use efficiency, and 
waste reduction. This set of criteria should be adopted as basis at the time to issue grants to sets of users.

Regardless of the values set to reduce the allowable pumping and/or the necessary water release downstream, the application of the simulation model may help finding ratios and proportions between them. As an example of application, the downstream release or effluent discharge of at least half of the upstream affluent flow in the exploited section was herein adopted as necessary condition for the sustainability of the aquifer exploitation.

Successive flow reductions in the wells were simulated until the relation between flows at the borders was satisfied. The best herein found solution pointed towards a drastic $73 \%$ reduction in meeting the total demands of the modeled area in order to assure that $48 \%$ of the affluent volume was released downstream.

The water balance applied to the last 15 days of the quarterly exploitation period presented the following values:

- Affluent volume across borders (upstream or downstream): $1,188.45 \mathrm{~m}^{3}$;

- Effluent volume across the downstream border: $569.25 \mathrm{~m}^{3}$;

- Volume pumped out of the wells: $624.00 \mathrm{~m}^{3}$;

- Variation in the stored or withdrawn volume: $4.80 \mathrm{~m}^{3}$.

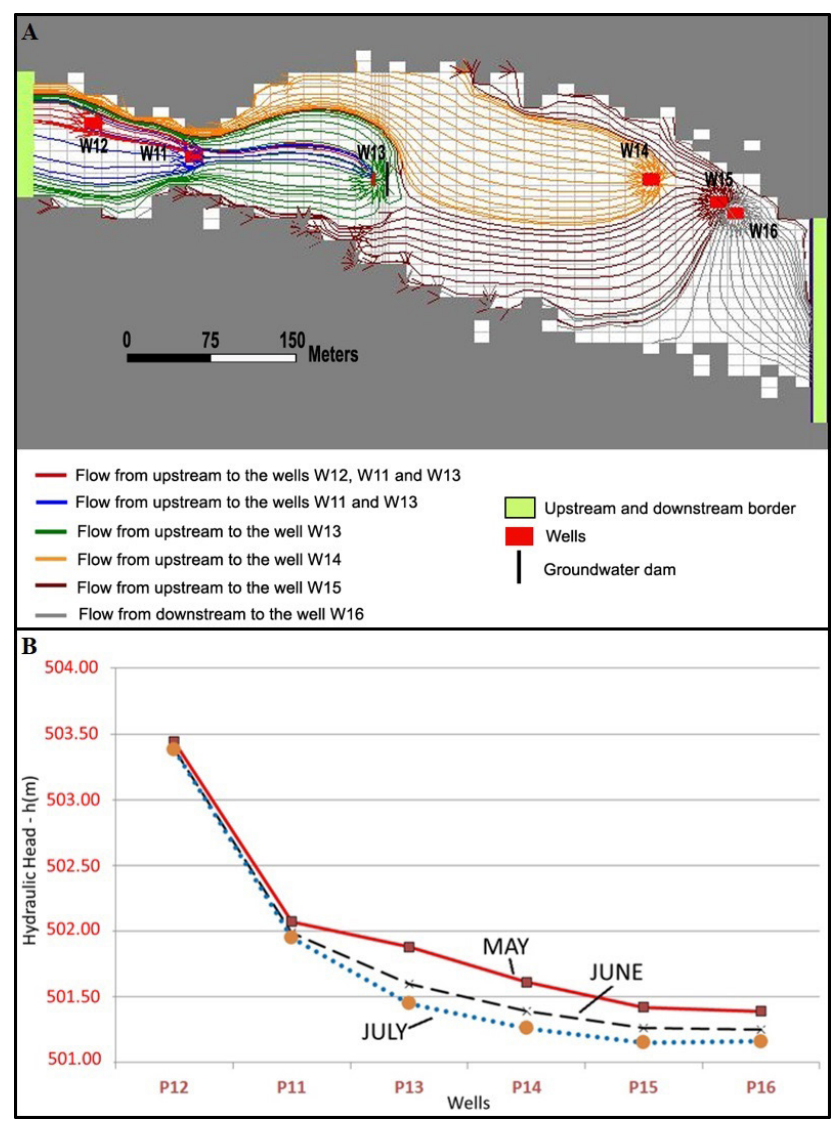

Figure 2. (A) Groundwater flow current lines at the end of three exploitation months with total supply of demands (Scenario 1: Prevalence of the current situation); (B) Hydraulic heads (in meters) in the wells in each simulation month.
The comparison between results in Scenarios 1 and 2 showed that the pumping reduction strongly influenced the storage withdrawals, which were extremely reduced. The affluent flows also decreased; however, they were sufficient to assure the desired effluent flow elevation.

According to the flow lines in Scenario 2, in the same critical period as in the previous scenario (Figure 3A), it is possible distinguishing the wells supplied by the upstream affluent flows at the Eastern border, whereas part of these flows goes downstream along the Western border. Scenario 2 also showed decreased hydraulic loads in each well in time, at the end of each month (Figure 3B).

\section{Scenario 3: the same as scenario 2, with modifications in well and dam arrangements}

The original distribution (locations) of the wells and dams in the exploitation area naturally followed land and/or economic reasons rather than hydrogeological ones. An example of it lies on the excessive proximity of the P14, P15 and P16 wells. This distribution concentrates the flow in the restricted area and leads to drawdowns due to mutual interference between its areas of influence, although there is enough space for more balanced distributions.

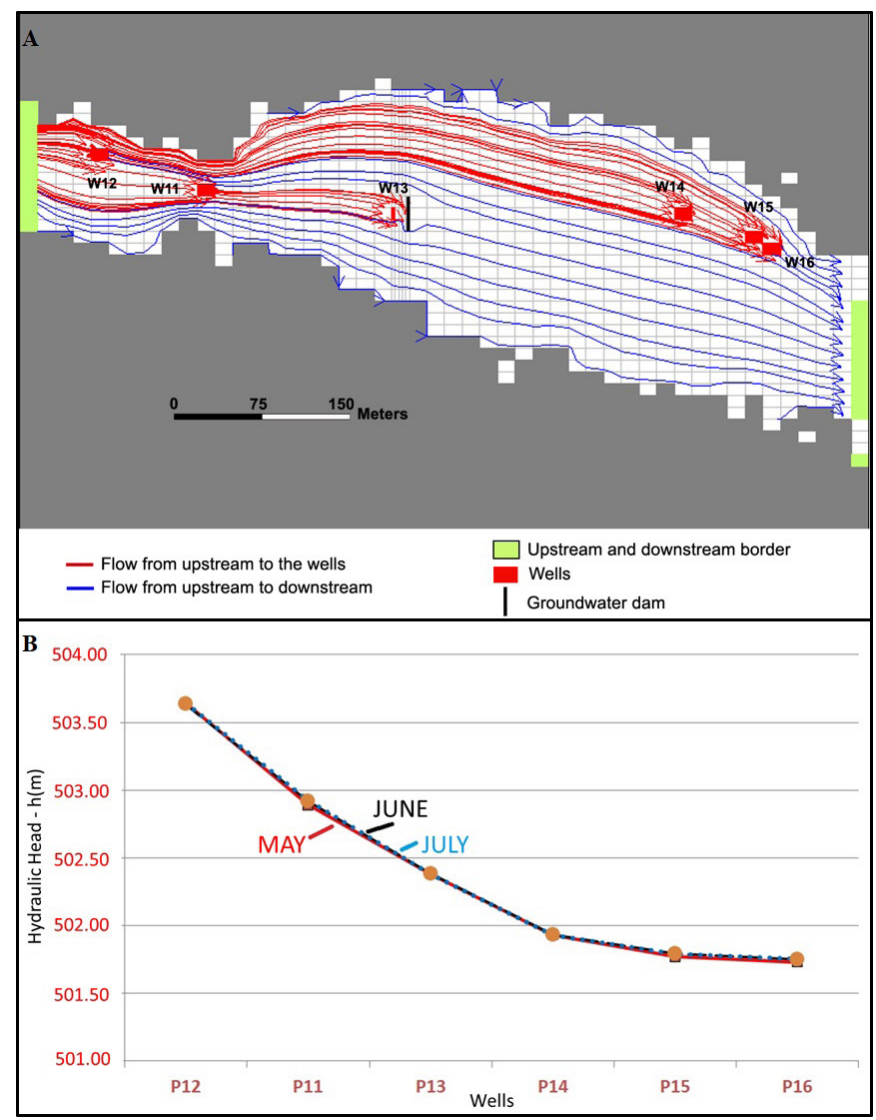

Figure 3. (A) Groundwater flow current lines at the end of three exploitation months, with partial supply of demands and downstream release (Scenario 2); (B) Hydraulic heads (in meters) in the wells in each simulation month. 
It would be possible simulating or optimizing the distribution of all wells in order to better meet the demand, but we made the option for making minor changes in the existing situation. Thus, the displacement of the P16 well towards near the Southern border of the aquifer was initially tested, but the results were not so different from those found in Scenario 2 as to justify the new distribution.

After several attempts, also chosen through the analysis applied to the hydraulic loads and flow lines, the herein found solution comprised displacing the P16 well, in association with the construction of a partially underground dam in the axis of the downstream border, in order to narrow the dam down (Figure 4A). Thus, it was possible assuring the release of $50.5 \%$ of the affluent flow by reducing $40 \%$ of the total met demand. The P11 well users will not need to reduce their irrigated area, whereas the P12 ones will not need to reduce their herd.

The water balance in the modeled area was applied to the last 15 days of the quarterly exploitation period, besides presenting the following values:

- Affluent volume across the borders (upstream or downstream): $224.10 \mathrm{~m}^{3}$;

- Effluent volume across the downstream border: $113.25 \mathrm{~m}^{3}$;

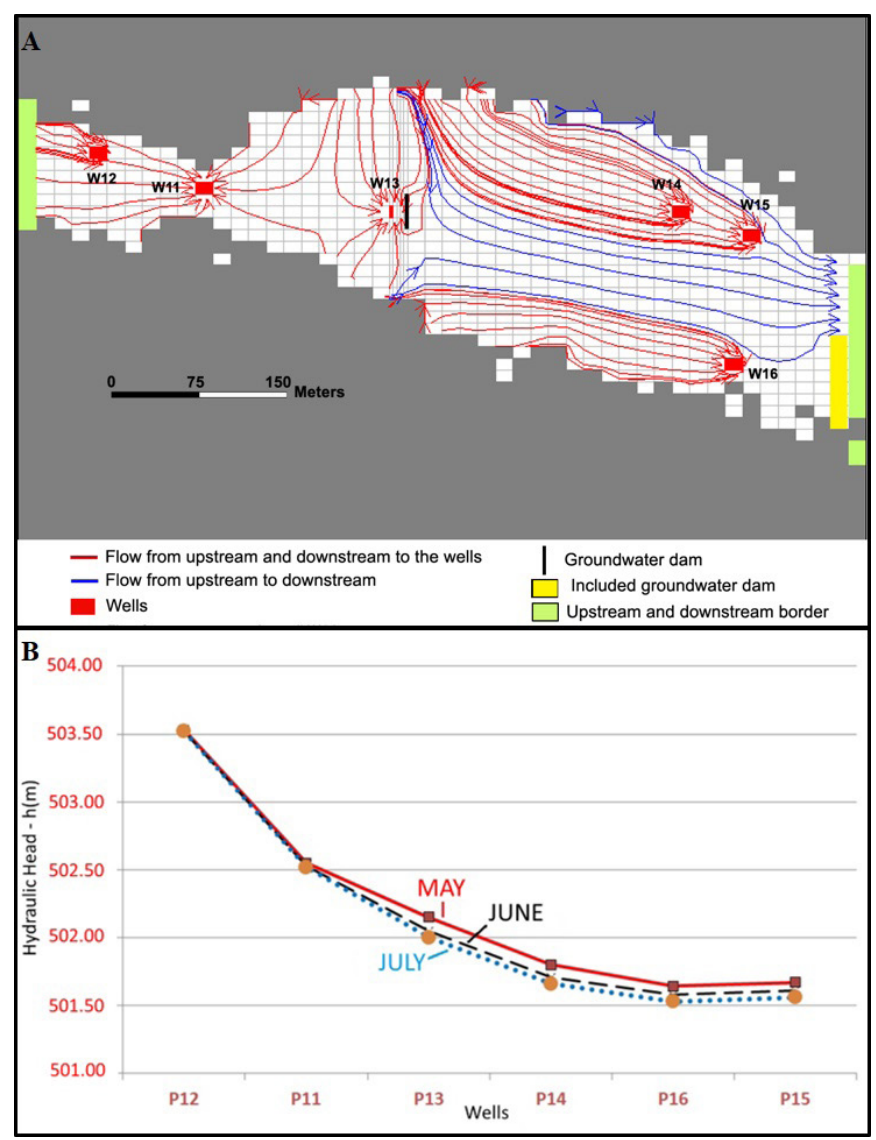

Figure 4. (A) Groundwater flow current lines at the end of three exploitation months, with partial supply of demands, downstream release, well reallocation and underground dam implementation (Scenario 3); (B) Hydraulic heads (in meters) in the wells in each simulation month.
- Volume pumped out of the wells: $1,399.95 \mathrm{~m}^{3}$;

- Variation in the stored or withdrawn volume: $1,289.10 \mathrm{~m}^{3}$.

The wells in Scenario 3 were preponderantly supplied by flows deriving from the aquifer storage in the modeled area. Consequently, the affluent flows have considerably decreased, whereas the effluent ones met the established criterion of reaching half of the affluent flows. Figure 4A shows the flow lines of Scenario 3 at the same critical period as that of the previous scenarios, i.e., at the end of three exploitation months. The perceptible flow divider between P11 and P13 attests to the role played by the storage, which was previously pointed out through water balance.

These results also highlight the strong influence of the underground dam on flow behavior (SILVA et al., 2004; RÊGO, 2012). In the present case, the dam does not occupy the whole cross section of the alluvium and is strongly linked to the aquifer border condition. Changes in the flow pattern result from the influence of these contour conditions, which were also taken into consideration in the current scenario, rather than from the reallocation of the well.

The joint analysis applied to results found in the herein simulated scenarios draws attention to the meanings that can be given to the management/sustainability criteria adopted in the current study. The assurance of downstream flow, which was taken as affluent flow percentage in the herein treated case, can mean very low values in absolute numbers. Thus, if one goes from Scenario 2 to Scenario 3, it is possible noticing that pumping increases by $33 \%$ (from $27 \%$ to $60 \%$ of the flow pumped in Scenario 1). However, the effluent volume drops from $569.25 \mathrm{~m}^{3}$ to $113.25 \mathrm{~m}^{3}$ in the last 15 days of the quarterly exploitation period.

The numbers emerging from the three herein analyzed scenarios point towards the real need of taking into consideration the river basin and the corresponding alluvial aquifer system as a whole, at the time to make exploitation-related decisions. Scenario 3 shows that exploitation management interventions may help increasing water availability without affecting other parts of the aquifer. The current study corroborates those conducted by Burte et al. (2005, 2009), Burte, Coudrain and Marlet (2011) and Monteiro, Montenegro and Montenegro (2014), who investigated similar aquifers in Ceará and Pernambuco states, respectively. Monteiro, Montenegro and Montenegro (2014) assessed recharge and leaching scenarios in order to investigate their impact on the potential for exploitation, i.e., they investigated the influence of supply-associated hydrological uncertainties. As for the study conducted in the aquifer in Ceará State, exploitation scenarios showed aquifer depletion and management alternatives were suggested by taking into consideration the integrated use of surface water deriving from reservoirs.

It is essential performing simulations focused on assessing and proposing exploitation alternatives in order to assure fairness and broad access to the water source in situations in which water supply systems are seasonally depleted due to relatively-low water availability. Overall, such exercise, and its consequent negotiated decision, happen within the scope of river basin committees, and often in the scope of specific management groups belonging to these committees, which were formed for such purpose. 
The limitation in the current study, as well as in several other hydrological studies about water availability in alluvial aquifers belonging to intermittent rivers in arid and semi-arid regions, consists in neglecting ecological flow and ecosystem preservation aspects. Ecosystems must be effectively seen as a demand (JACOBSON; JACOBSON, 2013); therefore, they must be taken into account in the grant issuing system.

\section{CONCLUSIONS}

If one disregards the upstream water inputs and the downstream water needs, the groundwater exploitation in isolated areas of alluvial aquifers in the Brazilian semi-arid region may compromise, or even render unfeasible, the exploitation of all aquifers. It mainly happens due to the reduction, or even the reversal, in the natural flow direction caused by local super-exploitations that do not respect the natural limitations or the prevailing socioeconomic conditions mainly expressed through the distributed demands.

Use limitations can be minimized through structural and operational measures such as proper well location, exploitation regime, and implementation of underground dams, among others. Computer simulations are effective in enabling the adequate definition of these measures. The modeling of scenarios allows flexibilizing alternatives, investigating groundwater flow trajectories, as well as making accurate water balance evaluations in areas presenting affluent, effluent and pumped flows, respectively.

The integrated analysis applied to the alluvial aquifer, by taking into consideration the entire river basin, is essential to the grant issuing process. The numerical modeling and scenario generation tool suggested in the current study may help indicating sustainable aquifer exploitation alternatives, by always taking into consideration negotiations between users, which are mediated by the river basin committee and managing body, in order to avoid water-access inequalities.

\section{ACKNOWLEDGEMENTS}

The authors are grateful to Project Bramar and to the following agencies for their financial support: CAPES, CNPq, FINEP/CT-HIDRO.

\section{REFERENCES}

ALBUQUERQUE, J. P. T.; RÊGO, J. C. O semiárido brasileiro: aspectos gerais. In: GALVÃO, C. O.; CIRILO, J. A.; CABRAL, J. J. S. P.; MEDEIROS, M. G. A. (Ed.). Recursos hídricos para a convivência com o semiárido: abordagens por pesquisadores no Brasil, Portugal, Cabo Verde, Estados Unidos e Argentina. 1. ed. Porto Alegre: ABRH, 2011. p. 19-47.

ATECEL. Estudo de aluviōes em um trecho do Rio Sucuru para Irrigação do Perímetro de Sumé. Campina Grande, 1999. Relatório final.

BRAGA, A. C. R.; RÊGO, J. C.; GALVÃO, C. O. Variação intrasazonal da potencialidade hídrica subterrânea e sua influência na outorga. Revista Brasileira de Recursos Hídricos, v. 20, n. 3, p. 647-656, 2015. http://dx.doi.org/10.21168/rbrh.v20n3.p647-656.
BURTE, J. D. P.; COUDRAIN, A.; MARLET, S. Use of water from small alluvial aquifers for irrigation in semi-arid regions. Revista Ciência Agronômica, v. 42, n. 3, p. 635-643, 2011. http:// dx.doi.org/10.1590/S1806-66902011000300009.

BURTE, J.; COUDRAIN, A.; FRISCHKORN, H.; CHAFFAUT, I.; KOSUTH, P. Impacts anthropiques sur les termes du bilan hydrologique d'un aquifère alluvial dans le Nordeste semi-aride, Brésil. Hydrological Sciences Journal, v. 50, n. 1, p. 95-110, 2005. http://dx.doi.org/10.1623/hysj.50.1.95.56337.

BURTE, J.; JAMIN, J. Y.; COUDRAIN, A.; FRISCHKORN, H.; MARTINS, E. S. Simulations of multipurpose water availability in a semi-arid catchment under different management strategies. Agricultural Water Management, v. 96, n. 8, p. 1181-1190, 2009. http://dx.doi.org/10.1016/j.agwat.2009.03.013.

CAROL, E.; KRUSE, E.; MANCUSO, M.; MELO, M. Local and regional water flow quantification in groundwater-dependent wetlands. Water Resources Management, v. 27, n. 3, p. 807-817, 2012. http://dx.doi.org/10.1007/s11269-012-0216-9.

CHIANG, W. H. 3D-groundwater modeling with PMWIN: a simulation system for modeling groundwater flow and transport processes. 2nd ed. Berlin: Springer, 2005.

JACOBSON, P. J.; JACOBSON, K. M. Hydrologic controls of physical and ecological processes in Namib Desert ephemeral rivers: implications for conservation and management. Journal of Arid Environments, v. 93, p. 80-93, 2013. http://dx.doi.org/10.1016/j. jaridenv.2012.01.010.

MCDONALD, M. G.; HARBAUGH, A. W. A modular threedimensional finite-difference ground-water flow model. Reston: United States Department of the Interior, USGS National Centre, 1984.

MONTEIRO, A. L. N.; MONTENEGRO, A. A. A.; MONTENEGRO, S. M. G. Modelagem de fluxo e análise do potencial hídrico de aquífero aluvial no semiárido de Pernambuco. Revista Brasileira de Recursos Hídricos, v. 19, n. 3, p. 151-163, 2014. http://dx.doi. org/10.21168/rbrh.v19n3.p151-163.

RÊGO, J. C. Bewirtschaftung kleiner allwialer Grundwasservorkommen im semiariden Nordosten Brasiliens. 2012. 178 f. Tese (Doutorado) Gottfried Wilhelm Leibniz Universität, Hannover, 2012.

SHANAFIELD, M.; COOK, P. G. Transmission losses, infiltration and groundwater recharge through ephemeral and intermittent streambeds: a review of applied methods. Journal of Hydrology (Amsterdam), v. 511, p. 518-529, 2014. http://dx.doi.org/10.1016/j. jhydrol.2014.01.068.

SILVA, F.; RABELO, J.; SRINIVASAN, V.; SCHUSTER, H. Uma investigação dos efeitos hidráulicos de barragens subterrâneas em um aquífero aluvial na região semi-árida da Paraíba. Revista Brasileira de Recursos Hídricos, v. 9, n. 3, p. 55-68, 2004. http:/ / dx.doi. org/10.21168/rbrh.v9n3.p55-68.

THORNTHWAITE, C. W.; MATHER, J. R. The water balance. Centerton: Laboratory of Climatology, Drexel Institute of Technology, 1955. 104 p. (Publications in Climatology, 8). 
VIEIRA, L. J. S.; RÊEGO, J. C.; SRINIVASAN, V. S. Aplicação de um modelo matemático de simulação do fluxo subterrâneo para definição de alternativas de explotação de um aquífero aluvial. In: SIMPÓSIO DE RECURSOS HÍDRICOS DO NORDESTE, 6 ., 2002, Maceió, AL. Anais... Porto Alegre: ABRH, 2002.

YANG, X. Application of the conceptualization groundwater data model to study the upper Arkansas river corridor, Western Kansas. Journal of Earth Science, v. 23, n. 1, p. 77-87, 2012. http:/ / dx.doi.org/10.1007/s12583-012-0234-9.

ZUME, J. T.; TARHULE, A. A. Modelling the response of an alluvial aquifer to anthropogenic and recharge stresses in the United States Southern great plains. Journal of Earth System Science, v. 120 , n. 4, p. 557-572, 2011. http://dx.doi.org/10.1007/s12040011-0088-z.

\section{Authors contributions}

Everton John Camelo Alves: Article conception; data collection and organisation; methodology definition; simulations execution; interpretation and discussion of results; manuscript preparation.

Janiro Costa Rêgo: Article conception; methodology definition; interpretation and discussion of results; manuscript preparation.

Carlos de Oliveira Galvão: Article conception; methodology definition; interpretation and discussion of results; manuscript preparation.

José Benito de Andrade Vieira: Data collection and organisation; simulations execution; interpretation and discussion of results. 